\title{
Cashing in on Natural Resource Mismanagement: A Study on Depleting Sasthamkotta Fresh Water Lake in Kerala
}

\author{
S. Mohammed Irshad \\ Jamsetji Tata School of Disaster Management, Tata Institute of Social Sciences, India
}

Copyright (C) 2015 by authors, all rights reserved. Authors agree that this article remains permanently open access under the terms of the Creative Commons Attribution License 4.0 International License

\begin{abstract}
There are many international agreements and treaties are exist to manage commons. The Ramsar Convention of 1971 was one among them. Many wetlands across the world have listed as Ramsar site. Ramsar Agreement meant to prevent depletion of the commons and put protective measures. However, this paper explains the depletion and bad protection of one of the wetlands listed in the Ramsar list-Sasthamkottaa Fresh Water Lake in Kerala, India. A part of the Sasthamkottaa Fresh Water Lake and the adjacent Kallada Rives are dried up due to sand mining, however, the local community and state (including local self-government) had not put any effort to prevent the lake from drying up within the jurisdiction. It results a total chaos in governing the wetland. The state government planned many protection measures; however, none of them got implemented. It results a legitimisation of the exploitation which influence the local resource governance
\end{abstract}

Keywords Common Pool Resources, Sasthamkotta Lake, Kallada River, Ramser Convention, Exploitation, Kerala Water Authority

\section{Introduction}

Wetland conservation is a globally accepted process, the Ramsar Convention in 1971 was, in fact,the first global agreement, which recognized the importance of preserving the wetlands. Implementation of the Ramser agreement is one among the many conservation methods to save the wetlands. United Nations Environment Program (2012) defined the importance of wetlands as the most biologically-varied areas that extend critical habitats for many species including coral reefs, peatlands, freshwater lakes, water birds, amphibians and wetland-dependent mammals such as hippopotamus, manatees and river dolphins. The global Ramsar Convention network covers more than 2,000 sites spread across 1.9 million kilometres.
Conservation and protection of natural resources are collective process with the active involvement of the people. The need and acceptance of 'development' often restricts the implementation of conservation policies. Conservation ideas are generally talks about optimum use of resources; however it is true to state that optimum use has been subjected to the idea of optimum capitalization of resources. It is difficult to establish a method for optimum utilization of resources, however it quite easy to place a mechanism to convert resources for economic use.

The case study explained in this paper, is about the exploitive utilization of a freshwater lake in the southern part of India - the Sasthamkotta Freshwater Lake in Kerala. The local media reported that about 46 acres of lake got dried up due to sand mining and water pumping. Kerala Water Authority (KWA) is the only agency which pump water for running the State Government's drinking water supply project in the district and sand mining is purely done by private sand sellers. This paper attempts to analyse the local communities silence support for sand mining for more than two decades and the current activists gathering for lake protection. It attempts to study why the local community is not resist the extensive sand mining from the nearby River Kallada, which later proved detrimental to the existence of the Sasthamkotta Freshwater Lake. The paper attempts to analyse why the local community have not mobilized themselves against the poor conservation of lake when they faces severe drinking water crisis $\left[{ }^{1}\right]$.

\section{Methodology and Conceptual Framework}

This study is based on field work and secondary sources

1 I had an interesting experience while doing the field work in the Sasthamkotta Lake area. A local tea vendor told me that there is no issue of drying up of lake here. Actually, about 46 acres of lake had been dried up exactly eight kilometre away from his tea shop. He was very critical about the local environment activists who mobilized a meeting in that day. This public perception plays a major role in sidelining the issue of drying up of the lake. 
collected from the local self-governments, interview with local activists and newspaper reports on the Sasthamkotta Lake. Hence, contend analysis of newspaper reports and the study conducted by the Centre for Water Resource Development and Management (CWRDM) were used to assess the reasons for the drying up of the lake. Newspaper reports and the CWRDM study proved that it took more than 20 years to reach the present status of the Lake. It is evident from the report and personal interview with the activists that, the local people are aware of the reasons for rive dry-up and they also put non-recyclable solid waste to the lake. It also revealed that the local people have not oppose the waste dumping till the media started reporting about it. This peculiar public attitude and support for the monetization of river resources is the analytical focus of this paper. Newspaper reports, local self-government reports, interviews with the president of one of the local self-government (Kallada Gram Panchayat) and group discussion with the environmental activists are the sources of this study. Common-property resource (CPR) governance is the major analytical focus of this paper. The paper takes the critical concern of governing commons and the conflict of interest with the local perception of monetization of resources, and the result of public silence towards conserving commons.

Every idea of common-pool resources begins with the reference to the tragedy of the commons thesis of Hardin (1968). He, in fact, predicts the overexploitation and eventual ruin of all common resources due to individual user's rational incentive to maximize utility. Schlager and Ostram (1992) have explained that common-property resources (CPR) mean:

1) Property owned by the government

2) Property owned by no one

3) Property owned and defended by a community of resource users

It also refers to any common-pool resource used by multiple individuals regardless of the type of property rights involved; de facto and de jure ownership affects the incentives the individuals get, the type of actions they take, and the outcomes they achieve. They further argue that the significance of such difference of ownerships is that there exists a clear point of departure between owners who hold a complete set of rights, and all other users who do not hold complete rights. Often the right to alienate a group or abstain from use is believed to be crucial for the efficient use of resources in the case of depleting sources. This theoretical proposition explains that the right to use resources could be transformed to use various patterns. In the case of Sasthamkotta Lake the local self-government is the legal owner and the local community owns the land on the bank of the rivers. It is expected to have conflicts of interests over the resources and in a democratic state agency expected to perform as agents of sustainable use of resources.

State agencies could mobilise or represent the collective action to preserve common-property resources. Collective action is a subjective one and it is directly associated with specific socio-economic context in which CPR is located and treated. Managing CPR in common ownership needs institutional support systems within the state. These support systems could either be formal or informal governing systems or approaches. Hackett (1992) observed that the success of the governance systems or approaches reflects only when there is a benefit from protecting the CPR and reduction in the aggregate appropriation below the non-cooperative appropriation game. Hackett also explained that appropriators maintain a neutral position to enhance the value of their investment when the government implements a monitoring on common-pool resources. The state could be an effective agency to ensure non-economic return from CPR. It could be ecological security or natural-resource security.

Holling (1978) explained four ways or views to assess nature - nature benign, nature ephemeral, nature perverse/tolerant and nature's resilience. The concepts of nature benign believe that the existence of natural resource directly depends on the action of ingenuity along with the skills on raw materials. According to him, the magnitude of resource availability is not directly derived from their supply instead it is derived from human skills. Thus, as per this perspective, any use of resource would have no effect on global stability. Nature ephemeral considers natural resource as limited and fragile. Hence, resource users prefer local autonomy in resource allocation. Nature perverse/tolerant considers the natural world as tolerant of resource depletion, yet only to a limit. Holling's argument is largely drawn from the reality of depletion of natural resources and this concept is very much applicable to the case this paper discusses. The critical question this paper raise is the 'local autonomy' over the resource; however, the local public has not exercised the autonomy for conserving the resources. The local autonomy has applied to make economic benefits rather than ecological security or sustainable use of resources. Selsky and Creahan (1996) explain that in a given condition, State prefers to enforce boundaries around a particular resource more effectively due to the sovereign coercive rights of the State. It leads to effective control over resource utilization. In the case of Sasthamkotta Lake, the local environmental activists and not the general public and local self-government demanded physical protection of the lake. Later on the Government of Kerala proposed boundary construction, however not yet implemented.

\section{Identity of Resource Existence}

Illich (1981) argued that ecosystems do not have their own self-identities and are not goal-directed. Ecosystem operates according to a natural biophysical logic. It is the human inhabitants or users that put values to ecosystems based on the values that they (humans) hold. This value 
would be natural phenomena existing in ecosystems, but it becomes commoditised into resources only when swept into an exchange economy. It also leads to multiple levels of access discrepancies. Stevenson (1991:8) defined the open-access resource as fragile, fugitive resource characterized by rivalry in exploitation. Hence, an extraction of resources would result in symmetric or asymmetric negative externalities. Institutions usually come into being as a result of the actions of humans and allow specific individuals and groups to reap advantages from altered social circumstances rather than allowing societies as a whole to capture efficiency gains. This theoretical proposition is true with regard to the utilization of Sasthamkotta Lake. The proposed physical boundaries do not prevent the KWA to collect water for its drinking supply operations. However, the success of it also depends on the manner in which KWA owns the lake. The government should accept this ownership, and it should be at the cost of preventing direct access to the local community. State agencies need to be strengthened to accommodate the cost of conservation. Singleton and Taylor (1992) argued that solving the collective-action problem is generally costly. According to them, any solution, in general, has three phases - first is identifying mutual possible gains to ensure the Pareto-optimality; the second is negotiating an agreement with one of them; and third is monitoring and enforcing it. Sasthamkotta Lake and Kallada River are subject to depletion due to monetary intervention of the local community and the State (water for drinking, water supply and revenue from giving licenses for sand mining), which creates an institutional structure to gain access to a particular common-pool resource. The local community and local self-government seek alliances with State actors to defend the primacy of their claims. It results in a situation in which the collective perception of CPR limits of an operational definition of 'raw material' and hence, governing the Lake resources becomes a business deal rather than CPR protection.

\section{Sasthamkotta Freshwater Lake}

Sasthamkotta Freshwater Lake, located in Kollam District of Kerala State, India is one among the 26 wetlands identified for intensive conservation and management under the Ministry of Environment and Forest. In 2002, Sasthamkotta Lake was declared as Ramsar sites, along with Ashtamudi and Vemband-Kol wetland $\left[{ }^{2}\right]$. The lake gets its water from direct rainfall over the lake, run-off from the upper catchments and subsurface run-off/underground recharge comprising the base flow from the catchment as well as from the extensive groundwater storage of the tertiary sedimentary province spreading outside the catchment, and recharge from the flood plain lying to the

2Sasthamkotta Lake Wetland Management Action Plan, Centre for Water Resources Development and Management, Kozhikode, Kerala
South of the lake and from River Kallada $\left[{ }^{3}\right]$. The main sources of water are direct rainfall and underground recharge. There are four outflows from the lake - spillage, groundwater seepage, evaporation from the lake surface and pumping by KWA for drinking water supply at the rate of $3.7 \mathrm{mld}\left[{ }^{4}\right]$.

In a meeting conducted by the Minister, Water Resource, Kerala, during May 2010, it was decided that CWRDM will set-up a committee to look into the various threats to the existence of the lake. The committee marked the following problems pertaining to the existence of lake:

Filling up of the shallow parts of the lake for cultivation

a) Pollution of the freshwater lake due to sanitary discharges and domestic sewage disposal

b) Large-scale destruction of the natural and manmade vegetation around the lake resulting in degradation of catchment areas and reduction in the depth of the lake and thereby its volume

c) Rapid sedimentation of the lake due to various activities in its adjoining catchment areas resulting in reduction in the depth of the lake and thereby its volume

d) Filling of the banks of the lake

e) Sand mining

f) Loss of biodiversity

g) Soil erosion and nutrient loss

h) Pollution from urban and agricultural sectors

i) Establishment of housing colonies along the fringes of the lake

j) Overgrazing and uncontrolled fishing

k) Weed infestation $\left[{ }^{5}\right]$

The main source of water for the lake is direct rainfall and infiltration of groundwater. A socioeconomic survey conducted by the Centre for Earth Scienec Studies (Now National Centre for Earth Science Studies) found that 41.1 per cent of the families living in the periphery of the lake are facing the crisis of drinking water. The lake serves as a sink for excess nutrients from the agricultural fields reaching it through runoff. These nutrients are used as a source for the freshwater flora and fauna.

\subsection{Major Threats to Sasthamkotta Lake}

The report explained that the population growth, urbanization and unscientific land and water resource development has resulted in the deterioration of water sources in Sasthamkotta Freshwater Lake. In 2010, an expert committee was appointed under the leadership of the Executive Director of CWRDM to study the reason for drying-up of the lake. The committee found that one of the major threats to the lake is soil erosion. The committee found that the deterioration of the lake at 50 tons/hectare/year in

3 Sasthamkotta Wetland Management Action Plan, Centre for Water Resources Development and Management, Kozhikode, Kerala

4Catchment conservation/development plan for Sasthamkotta Lake, Kollam District, Centre for Earth Science Studies, 1998.

5 SasthamkottaWetland Management Action Plan, Centre for Water Resources Development and Management, Kozhikode, Kerala, 2010. 
1996 itself; and it had extended due to human interventions. Other threats were mining of hillocks and resultant reduction in groundwater inflow to the lake. Hillocks in the lake catchments act as a groundwater reservoir, which store water during the monsoon periods and release it to the downstream lake system. Several of such hillocks were mined for construction purpose. Sand/clay mining had resulted in increasing groundwater outflow from the lake. Clay-mining and sand mining from the low-lying areas resulted in lowering the bed levels in the lake in out-of-flow proportion increasing the hydraulic gradient, which in turn, increased the subsurface flows from the lake system. Encroachment was also posing a threat to the lake as the slop areas of the lake have been encroached for tapioca and other plantations. The slop areas of the lake, subjected to agricultural practices, have led to soil erosion and have reduced the reservoir capacity. The southern periphery of the lake, which are vast floodplains cultivated for paddy, was actually capable to function as a natural infiltration gallery to recharge the lake during rainy season. The expert committee mentioned the following threats:

a) Decrease in biological diversity such as degradation of sacred groves and depletion of traditionally-harbouring forest species.

b) Reduction in subsurface recharging, large-scale sand extraction from the adjacent floodplain in the eastern and south-western side of the lake hampered the subsurface recharging.

c) Water quality is also getting deteriorated due to the direct human intervention and waste disposal.

d) Population pressure and large-scale mining of lateritic hillocks also threatened the lake.

The report of CWRDM confirmed the fact that the Sasthamkotta Lake is drying and also explained the reasons for it.

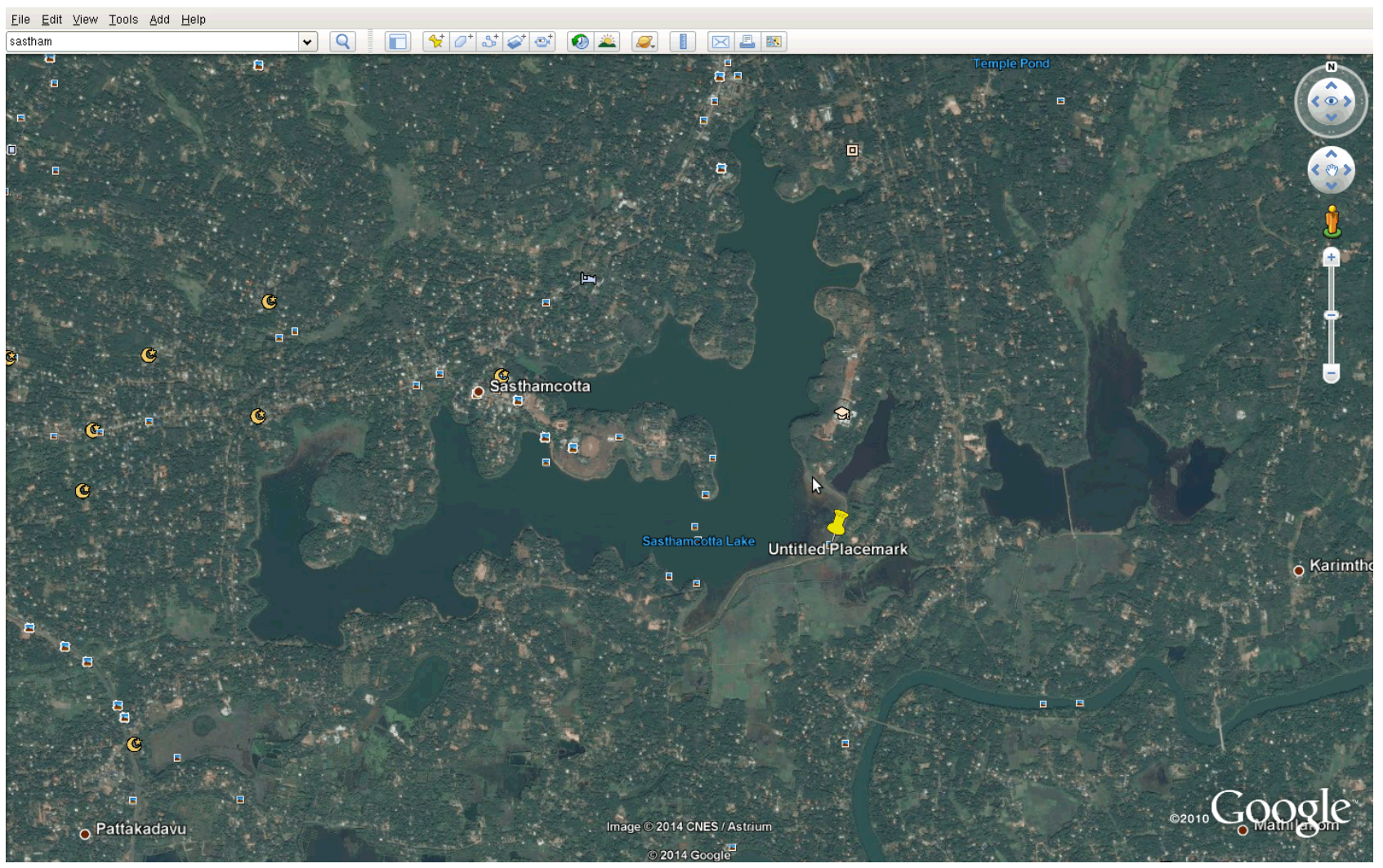

Figure 1. 


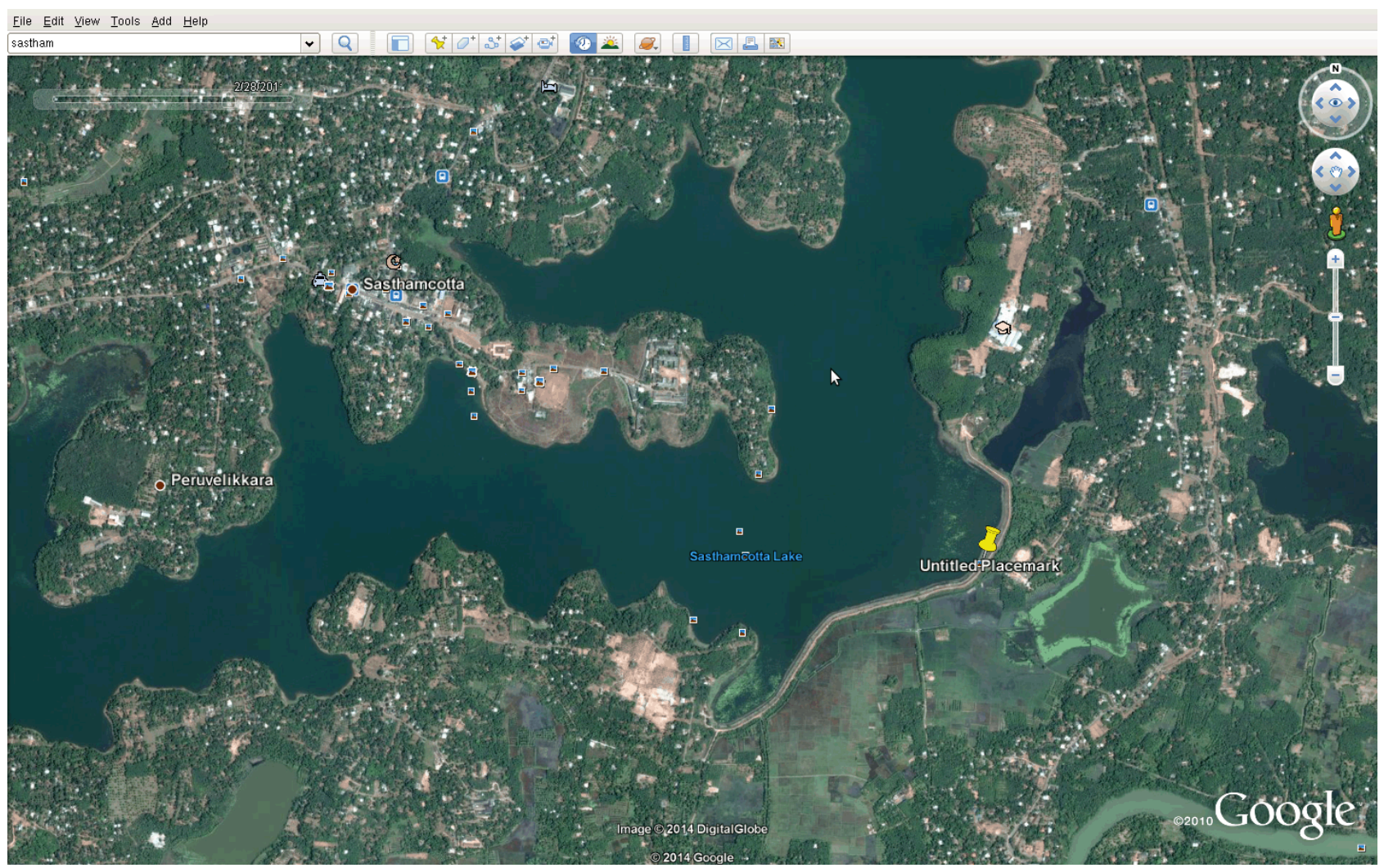

Figure 2.

\subsection{Lake Protection: Rhetoric and Reality}

The lake is spread across three Panchayats (Villages) in the district, and these local self-governments have the power and rights to design policy to protect the lake. Extensive sand mining is a major issue, which is evident from the letter written by the District Collector of Kollam to the District Police Chief stating that mining of sand and clay from the critical areas of KalladaRiver causes the passage of saline water from the KalladaRiver to Sasthamkotta Lake. The letter indicates the likely impact of saline water intrusion on drinking water supply of Kollam District. However, not much work has been done by the local governments towards protecting the KalladaRiver and Sasthamkotta Lake. In fact, the problems of lake protection started with the declining agricultural activities in the Kallada village. Mathrubhumi(a Malayalam daily) dated 18/11/2011 report that the transformation of paddy fields for clay mining badly affected the local environment and this led to the encroachment of water resources. Still there is 400 acres of agricultural land in the village and as per the local people and the local agricultural office, 820 acres of paddy field has been converted for clay-mining.

In 1998, CWRDM declared a plan of Rs 3.13 crore to protect the lake; however, no work was done to protect the lake. Another project was sanctioned in 2000, but no work was initiated. In 2005, another declaration came to protect the lake, and again in 2006, another project was declared, but as usual, no proper action was taken to follow it up.
In the meantime, the Kallada Panchayat has introduced a project of wind-power generation in the mined-paddy land with the shareholding support of the landowners. 350 acres of paddy land, owned by 15 families, was given away for clay-mining. Now, the Panchayat is planning to give share, according to the landholding pattern. In the current situation, no farming is possible on this land. This is a Public Private Partnership (PPP) project.The Kerala State Electricity Board will purchase the electricity from the project. This paper is not going into the details of the agreement. What is more interesting is the economic returns for the landowners from the deal. They were getting income from clay-mining, but it led to the destruction of the KalladaRiver and the Sasthamkotta Lake, and now, they are getting another benefit. Extensive clay-mining had a severe impact on the paddy cultivation and it is a fact that the landowners have not been exposed to any crisis associated with clay-mining and other environmental challenges. Such perception really impinged on the lake management, hence the local community and state are for monetising the lake resources.

\section{Private Gain and Public Loss}

The impact of sand mining from the catchment area of River Kallada and clay mining from the paddy field has critically impacted the KalladaRiver. In 1998, a group of activists from Kallada filed a case in the High Court of Kerala to stop sand mining. Following this, the High Court had issued an order to ban sand mining from the lake. 
However, the High Court order was not properly implemented. Again in 2000, another High Court verdict asked the district administration and local self-government to put up police picketing to stop sand mining. But as similar to the 1998 court verdict, this was also not implemented. Mathrubhumi daily dated November 20, 2011 reported that even the local police were supporting sand mining. It reported that police did not even listen to the complaints related to sand mining. In 2007, it referred a Public Interests Litigation (PIL) in High Court requesting to ban sand mining. Considering the PIL, Justice ThottathilRadhikrishan issued a verdict to implement a total ban of sand mining on the embankment of River Kallada. It was also not implemented. In 2009, the District Environmental Coordination Council approached the Lokayukta. In response to this plea, Lokayukta directed the District Police Superintendent and the District Collector of Kollam to implement the High Court verdict. All these interventions are set aside by the government, and sand mining still continues.

The most critical concern for the sustainability of the lake is the approach of local self-governments in the catchment area of the lake. Sand mining from KalladaRiver and Paddy land are supported by local self-governments. It is true that Sasthamkottalake depends onKallada River. Hence, any destruction of the Kallada River needs to be analyzed in this perspective. To know the details of conservation projects implemented to protect Sasthamkottalake and Kallada River along with licenses given for mining, the author of this paper filed an application under the Right to Information Act, 2005 to the Gram Panchayat (local self-governments), West Kallada, Sasthamkotta and Mynagappally. The reply from these local self-governments is important. It explains how irresponsible the State is towards the protection of Sasthamkotta Lake and KalladaRiver.WestKallada Gram Panchayat replied that (No. A1-4443/13-dated November 16, 2013) the Gram Panchayat had not implemented any measures, which were recommended by the State of Kerala to protect Sasthamkotta Lake. It also mentioned that West Kallada Gram Panchayat did not give any license to do sand mining from Sasthamkotta Lake. However, it issued 21,820 passes (licenses), and Rs. 2,15,88,500 have been collected as license fee from the year 2000 to the date of the reply. Sasthamkotta Gram Panchayat (No. C3-7442/13-dated November 13, 2013) has put the protection cover made up of cornet across the edges under Mahatma Gandhi National Rural Employment Guarantee Act. It spent Rs. 10,22,952 for this. Madhyamam daily on 12th June 2015 reported that the Government of Kerala banned sand mining from six rivers, including the Kallada River for three years. The decision is based on the sand auditing conducted by the National Centre for Earth Science Studies and other agencies. These decisions are good for Kallada River's existence, however, does not save the already dried up Sasthamkotta Lake.

There were many schemes and declarations announced by the State Government, but none of them have been implemented. A special lake authority for Sasthamkotta Lake was announced but not implemented.

\section{Discussion and Conclusions}

Sasthamkotta Lake andKallada River are the major sources of piped water supply in Kollam District. Hence, drying up of the lake would have serious implications on the piped water supply in the district. The irony is that the people live near the dried up areas of Sasthamkotta Lake are depended on tankerwater supply by the local self-government during the summer season. The local environmental activists and newspapers reported that about 46 acres of lake are dried up. Rejuvenation of the dried up area is a forgone idea, so it is going to be a permanent loss. Though areas have been dried up, it has not affected the pumping of water from the lake. The Hindu daily dated April 5, 2013 reported that the KWA was planning to install an additional $450 \mathrm{hp}$ pump to draw water from Sasthamkotta Lake. As per the report, KWA has an installed capacity to treat 37.5 million litres of water per day for the latest drinking water supply project constructed with the help of The World Bank and the Asian Development Bank as part of the Tsunami Rehabilitation Project $\left[{ }^{6}\right]$.

It is a fact that nobody can suggest a solution to the problem of drying up of lake and sand mining. Sand mining still continues in full public view. Hence, the idea of vigilant civil society to stop sand mining is alost concept. The local people knew the persons who were in the business of sand mining and it took nearly two decades for some of the local environmental activists to gather themselves to fight for the lake. Their demands are:

a) Stop additional pumping of water

b) Set up separate Sasthamkotta Lake Authority

c) Stop sand mining

d) Fencing around the lake

These are many important support systems available to protect the lake. The Lake protection committee raised an interesting demand to stop additional pumping of water for the Chavara scheme, according to them the project and beneficiaries are not belong to the Kallada area. This could be a kind of water conflict resulted by monetisation and poor management of commons. Two decades of sand mining from Sasthamkotta Lake and the public silence forces us to revisit the idea of public responsibility in protecting natural resources. It is true to state that the local people are beneficiaries of sand mining (financial gain) and they are the beneficiaries of ecological services from the lake as well. The idea of ecological security is missing from the public perception and the monetary value of resources has impinged on even the popular imagination of environmental conservation. It has also influenced government's intervention in protecting the lake. The public silence indeed justifies the capitalist mode of resource use and it leads to the delay in implementing State's conservation projects. It also questioned the established concern of public support to environmental conservation. The studies and assessment

6 Kerala Water Authority initiated a drinking water supply project in Chavara Area with the capacity of storing 18 lakh litre of water. KWA is also pumping water from Sasthamkotta Lake. 
done by various agencies on the Lake have not made any substantial change in the river conservation approach. It is quite possible to impose a local tax to raise capital for conserving the remaining part of Lake.

\section{Acknowledgements}

I acknowledge the support extended by Mr Trideep, president of West Kallada Gramapanchayat, Mr Babuji, environmental activist and R L Rejith, Assistant Professor, Maharajas College, Ernakulam for the support.

\section{REFERENCES}

[1] Agrawal A 2003 Sustainable Governance of Common-Pool Resources: Context, Methods, and Politics, Annual Review of Anthropology, 32 243-262

[2] Hackett SC 1992 Heterogeneity and the Provision of Governance for Common-Pool Resources, Journal of Theoretical Politics 4325

[3] Hardin G 1968 The Tragedy of the Commons, Science New Series, 162 1243-1248
Holling CS 1978 Myths of ecological stability: Resilience and the problem of failure, in Studies in Crisis Management (eds.) CF Smart and WT Stanbury, Montreal: Butterworth for the Institute for Research on Public Policy, 97-109 pages

[4] Illich I 1981 Shadow work, Boston: Marion Boyars

[5] Posner R 1975 Economic Analysis of Law, in Economic Foundations of Property Law (ed.) Ackerman B, Boston: Little, Brown and Co

[6] Edella S and Ostrom E 1992 Property-Rights Regimes and Natural Resources: A Conceptual Analysis, Land Economics, 68 249-262

[7] Selsky JW and Creahan S 1996 The Exploitation of Common Property Natural Resources: A Social Ecology Perspective, Organization Environment 9346

[8] Singleton S and Taylor M 1992 Common Property, Collective Action and Community, Journal of Theoretical Politics 4 309-324

[9] Stevenson GG 1991 Common Property Economics A General Theory and Land Use Applications, Cambridge University Press

[10] United Nations Environment Programme 2012 Conference of the parties to the Convention on biological diversity, Hyderabad, India, 8-19 October 2012

(http://www.cbd.int/doc/meetings/cop/cop-11/information/co p-11-inf-22-en.pdf). 